\title{
Fluid mixing from below in unconformity-related hydrothermal ore deposits
}

\author{
Paul D. Bons ${ }^{1}$, Tobias Fusswinkel ${ }^{2}$, Enrique Gomez-Rivas ${ }^{1,3}$, Gregor Markl ${ }^{1}$, \\ Thomas Wagner ${ }^{2}$, and Benjamin Walter ${ }^{1}$ \\ ${ }^{1}$ Department of Geosciences, Eberhard Karls University Tübingen, \\ Wilhelmstr. 56, 72074 Tübingen, Germany \\ ${ }^{2}$ Department of Geosciences and Geography, University of Helsinki, Gustaf \\ Hällströmin katu 2a, FI-00014 Helsinki, Finland \\ ${ }^{3}$ Department of Geology and Petroleum Geology, School of Geosciences, \\ King's College, University of Aberdeen, Aberdeen AB24 3UE, UK
}

\section{Accepted 3 September 2014, Published online 15 October 2014}

Published in Geology, 42 (12), 1035-1038. doi:10.1130/G35708.1

This is an author version of the manuscript. You can access the fulltext (copy-edited publishers version) at: http://geology.gsapubs.org/content/early/2014/10/14/G35708.1.abstract

\begin{abstract}
Unconformity-related hydrothermal ore deposits typically form by mixing of hot, deep, rock-buffered basement brines and cooler fluids derived from the surface or overlying sediments. Current models invoking simultaneous downward and upward flow of the mixing fluids are inconsistent with fluid overpressure indicated by fracturing and brecciation, fast fluid flow suggested by thermal disequilibrium, and small-scale fluid composition variations indicated by fluid inclusion analyses. We propose a new model where fluids first descend, then evolve while residing in pores and later ascend. We use the hydrothermal ore deposits of the Schwarzwald district in southwest Germany as an example. Oldest fluids reach the greatest depths, where long residence times and elevated temperatures allow them to equilibrate with their host rock, to reach high salinity, and to scavenge metals. Youngest fluids can only penetrate to shallower depths and can (partially) retain their original signatures. When fluids are released from different levels of the crustal column, these fluids mix during rapid ascent in hydrofractures to form hydrothermal ore deposits. Mixing from below during ascent provides a viable hydromechanical mechanism to explain the common phenomenon of mixed shallow and deep fluids in the formation of hydrothermal ore deposits.
\end{abstract}




\section{Introduction}

Mixing of fluids from different origins is often invoked for major unconformity-related hydrothermal ore deposits that have formed in a variety of geological contexts, such as the world class U deposits of the Athabasca basin (Canada) and McArthur River (Australia), and the $\mathrm{Pb}-\mathrm{Zn}-(\mathrm{Ag})$ deposits of the Irish Midlands, the Alaskan Brooke Range, the Massif Central (France) and Upper Silesia (Poland), among others. Geochemical evidence for fluid mixing comes from stable and radiogenic isotope signatures, mineral composition data and fluid-inclusion compositions, including halogen ratios (Goldhaber et al., 1995; Staude et al., 2009, 2012; Boiron et al., 2010; Wilkinson, 2010; Kendrick et al., 2011; Fusswinkel et al., 2013). Mesozoic, unconformity-related hydrothermal deposits of the Schwarzwald district in SW Germany are representative of a large range of deposits where mixing of (1) hot, basement-derived fluids from below, and (2) cooler, surface or sediment-derived fluids from above is invoked in the absence of igneous activity to drive fluid circulation (Staude et al., 2009, 2012 and references therein). Fluid circulation driven by topography or igneous activity can be excluded for the Mesozoic deposits in the Schwarzwald (Staude et al., 2009, 2012).

While the geochemical evidence of mixing processes appears undeniable, it is unclear how the mixing process proceeds physically. Some authors propose fluid flow trajectories that converge on the ore deposition site where mixing takes place (e.g. Boiron et al., 2010; Kendrick et al., 2011). This would imply a local low in the hydraulic head field, violating the condition of a divergence-free potential field in the absence of fluid sinks (Bons et al., 2012). Even if such a low would occur by dilation, it would only be transient, as the influx of fluids would quickly raise the local hydraulic head.

Large-scale fluid circulation has been proposed and modeled to explain the infiltration of surface-derived fluids down to mid-crustal levels (e.g. Matthi et al., 2004; Oliver et al., 2006a; Person et al., 2007). However, these models assumed a hydrostatic background fluid pressure gradient throughout the whole system, necessary to achieve convection, but unrealistic at depths where rocks mainly deform by ductile flow and cannot maintain large differences between hydrostatic fluid pressure and lithostatic pressure (ca. $100 \mathrm{MPa}$ and $270 \mathrm{MPa}$ at $10 \mathrm{~km}$ depth, respectively). Compaction and fracture sealing would reduce porosity and permeability at such depths and fluid pressure would rise. In the models, permeability and porosity are usually kept constant, ignoring these effects. Hydrothermal ore deposits typically show evidence of fluid overpressure such as repeated fracturing and brecciation (Cox, 2010; Weisheit et al., 2013). Fluid overpressure is difficult to reconcile with a fluid pressure gradient that is overall close to hydrostatic, or with convergent fluid flow.

Hydrothermal fluids are, by definition (Davies and Smith, 2006), hotter than their surroundings. In case of slow fluid percolation, fluid and matrix temperature remain in local equilibrium (de Marsily, 1986). The average distance, $\langle x\rangle$, from a perturbation, over which heat diffuses, by conduction alone, over a time interval, $t$, is determined by the thermal diffusivity, here taken as $D_{T}=10^{-6} \mathrm{~m}^{2} / \mathrm{s}$, through:

$$
\langle x\rangle=\sqrt{D_{t} \Delta t}
$$

Taking, for example, $\Delta t=800$ k.y., as used by Matthi et al. (2004), gives $\langle x\rangle \approx 5 \mathrm{~km}$. This means that the elevated temperature found in a hydrothermal deposit should spread over a few kilometers, if duration of fluid flow is on the order of hundreds of thousands of years. For the thermal perturbation to spread over only a few meters, i.e., $\langle x\rangle \sim 1 \mathrm{~m}$, duration of fluid flow should be on the order of 10 days at most. It follows that flow rates must be more than six orders of magnitude faster than assumed in classical percolative flow models, such as that of Matthi et al. (2004), and that therefore Darcy flow through porous media does not apply. Instead, flow must occur in short bursts of fracture flow (Bons, 2001; Bons and van Milligen, 2001). Fluid ascent in hydrofractures can potentially 
reach velocities of meters per second in the case of aqueous fluids (Dahm, 2000). Minimum ascent velocities of $>0.01 \mathrm{~m} / \mathrm{s}$ were estimated for natural veins from the Sanbagawa belt in Japan (Okamoto and Tsuchiya, 2009) and $>1 \mathrm{~m} / \mathrm{s}$ for fluidized hydrothermal breccia pipes from Cloncurry, Australia (Oliver et al., 2006b). With tectonic events leading to hydrothermal activity probably lasting hundreds of thousands of years to even $>100$ m.y. (Weisheit et al., 2013), and fluid flow events lasting on the order of days, these bursts would occur months, if not years, apart (Bons, 2001).

In summary, brecciation, indicating fluid overpressure (except in the case of implosion breccias), and strong thermal disequilibrium (Wagner et al., 2010; Beaudoin et al., 2014), indicating fast fluid flow, are incompatible with common models of crustal-scale fluid circulation. The hydrothermal ore deposits in the Schwarzwald (Fig. 1A) show clear evidence for fluid mixing (Fusswinkel et al., 2013). Staude et al. (2009) argued that sufficient fluid volumes to produce the deposits could have been released from below the deposits. Here we propose a new model integrating these observations and accounting for transport and mixing in a physically plausible way. Fluids first descended below an unconformity and were later released and expelled upwards, when mixing of fluids with contrasting geochemical signatures occurred.

\section{Hydrothermal systems of the Schwarzwald district}

The Schwarzwald district in southwest Germany combines a well-known, variable geology with $>1000$ hydrothermal mineral deposits (Fig. 1A). It consists of Variscan basement (mostly S-type granites and gneisses), which is unconformably overlain by a 1.5 -km-thick succession of PermianTriassic and Jurassic clastic sediments and limestones. Of particular relevance is a $250 \mathrm{Ma}, \sim 100$-m-thick evaporite sequence (up to the halite stage) intercalated in the Triassic limestones. Due to Paleogene tectonic tilting, the whole succession is exposed from the Jurassic in the east down to $\sim 2 \mathrm{~km}$ below the unconformity in the southwest. The hydrothermal veins occur within both basement rocks and the sedimentary cover. Formation ages indicate hydrothermal activity since Variscan times, peaking in the Jurassic, at which time the area was covered by a shallow sea and no significant tectonic or igneous activity is known (Staude et al., 2009, and references therein).

The deposits are fracture-hosted veins with breccias that indicate repeated fracturing and mineral precipitation. There is no known significant fault activity at the time of ore formation, and the deposits lack evidence for tectonic movements along the fractures. This suggests that space for mineral precipitation was produced by overpressured fluids. Fluidinclusion studies (Staude et al., 2012, and references therein) demonstrate temperatures of $\sim 150 \pm 50{ }^{\circ} \mathrm{C}$ for the Jurassic fluids. For veins formed at $23 \mathrm{~km}$ depth, this is more than $50{ }^{\circ} \mathrm{C}$ hotter than the country rock, while fluid pressure may reach $20 \mathrm{MPa}$ in excess of ambient pressure (Baatartsogt et al., 2007).

Geochemical and isotopic data indicate mixing of contrasting fluids that have characteristics of typical basement brines and sedimentary formation waters (Schwinn et al., 2006; Staude et al., 2012; Fusswinkel et al., 2013). Fusswinkel et al. (2013) analyzed a single crystal in a basement-hosted vein mineralization ( $1 \mathrm{~km}$ below the unconformity) of Jurassic age and found evidence for mixing of two distinct fluid end members (Fig. 1B). One is a hot, saline $\left(22 \pm 2 \mathrm{wt} \% \mathrm{NaCl}+\mathrm{CaCl}_{2}\right)$, rock-buffered brine with elevated base metal $(\mathrm{Zn}, \mathrm{Pb})$ content and low $\mathrm{Cl} / \mathrm{Br}$ mass ratios $(<100)$. The other end member is equally saline, is metal poor, and has high $\mathrm{Cl} / \mathrm{Br}$ ratios that indicate dissolution of halite, for which the only candidates are the Triassic evaporites. The data obtained by laser ablationinductively coupled plasmamass spectrometry analysis of individual fluid inclusions show a remarkable variation in fluid composition at the scale of individual growth zones. Such variations could only have been recorded if the different fluids had very little contact time, and therefore flow rates were high, as diffusion would have quickly equalized compositions (cf. Equation 1). Crush-leach and microthermometry analyses on fluid inclusions 
in gangue minerals in a number of ore deposits confirm that the strongly varying $\mathrm{Cl} / \mathrm{Br}$ ratios and relatively constant salinities are found throughout the southern Schwarzwald (Fig. 1B; see the GSA Data Repository ${ }^{1}$ for methods, and Table DR1 therein).
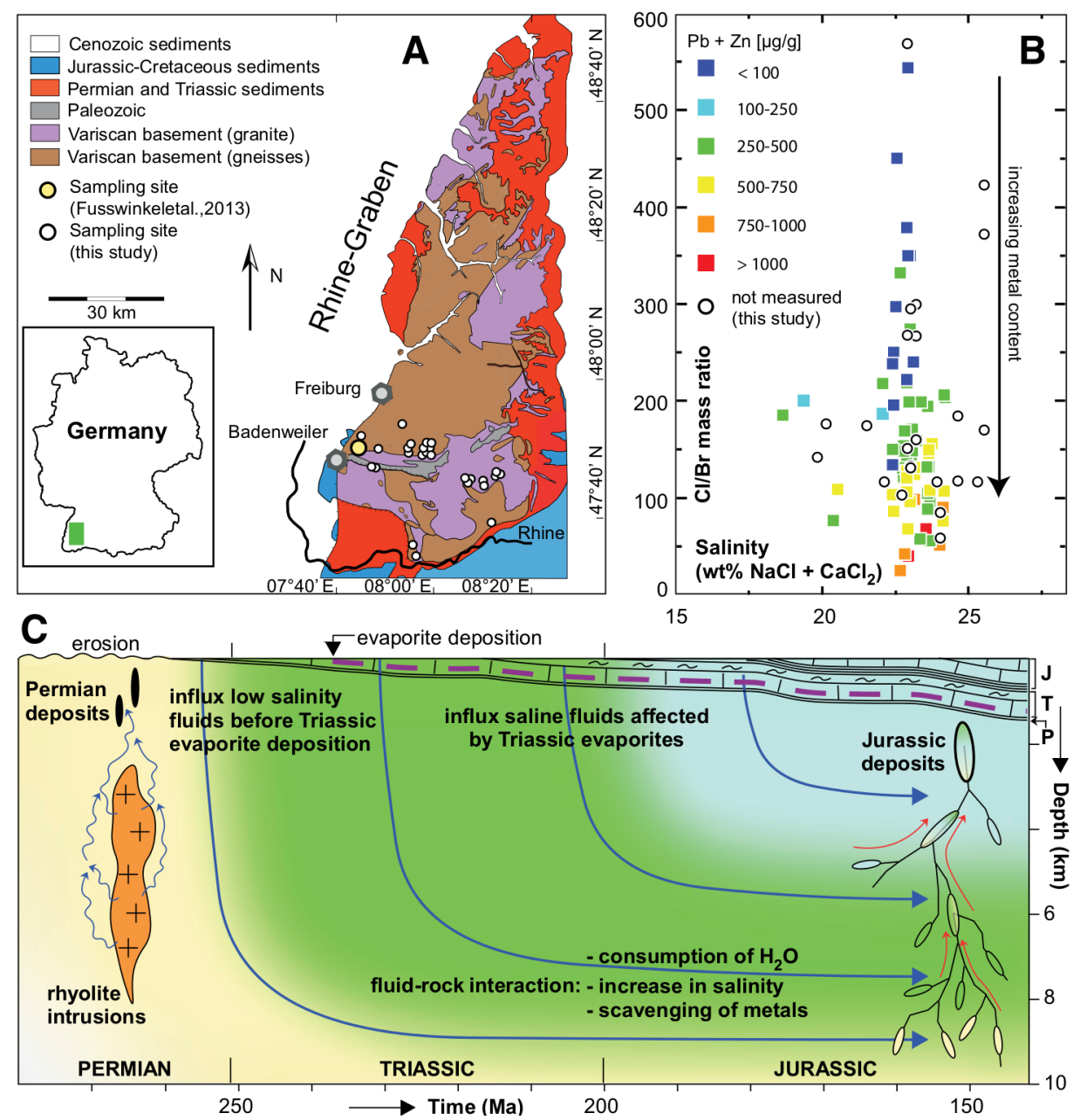

Figure 1: A: Simplified geological map of southern Schwarzwald district in southwestern Germany (modified after Hann and Zedler, 2008), showing locations of study area and sample sites. B: $\mathrm{Cl} / \mathrm{Br}$ ratios versus salinity of fluid inclusions in hydrothermal veins at localities shown in A. Colored squares are microthermometry and in-situ laser ablationinductively coupled plasmamass spectrometry data of fluid inclusions from a single quartz crystal presented by Fusswinkel et al. (2013), showing sample-scale covariation of decreasing metal contents with increasing $\mathrm{Cl} / \mathrm{Br}$ ratio. Open circles are for microthermometry and crush-leach analyses on gangue minerals from several localities in the Schwarzwald district, encompassing the same range in halogen ratios (see Table DR1 [see footnote 1]). C: Schematic diagram illustrating fluid evolution in Schwarzwald basement and overlying Permian (P), Triassic (T), and Jurassic $(\mathrm{J})$ sediments, from first exhumation in the Permian (left) to Jurassic formation of hydrothermal ore (right). Blue arrows show fluid pathways in space (vertical) and time (horizontal). Oldest fluids (yellow) infiltrated in the Permian and penetrated deepest levels. Triassic (green) and Jurassic (blue) fluids descended less and had shorter residence times. Fractures tapped and mixed fluids from all levels of the crustal column during ore formation.

\footnotetext{
${ }^{1}$ GSA Data Repository item 2014359, crush-leach and microthermometry method and data, is available online at www.geosociety.org/pubs/ft2014.htm, or on request from editing@geosociety.org or Documents Secretary, GSA, P.O. Box 9140, Boulder, CO 80301, USA.
} 


\section{Getting fluids down}

Following the Variscan orogeny, the crystalline basement of the Schwarzwald was exhumed during the Permian. Fluid inclusions in Permian quartz ( $\pm \mathrm{Sb}$ ) veins have low $(0-5 \mathrm{wt} \%)$ salinities and are mostly barren (Staude et al., 2009). This indicates that fluids in the crystalline basement were not yet saline and that the observed high salinities in Mesozoic fluids must have developed later. The German Continental Deep Drilling Project (KTB) encountered fluid-filled porosity down to a depth of $9 \mathrm{~km}$ (Emmermann and Lauterjung, 1997). From this, we infer that the exhumed Schwarzwald basement would have been infiltrated or soaked with fluids from above, down to at least similar depths $(\sim 10 \mathrm{~km})$, starting in the Permian.

In the absence of a topographic drive, downflow may have been caused by desiccation of fluids via mineral hydration reactions at depth (Stober and Bucher, 2004; Bons and Gomez-Rivas, 2013), causing a downward flux to replenish consumed $\mathrm{H}_{2} \mathrm{O}$. The source of these fluids was initially surface fluid (rainwater or seawater) and later fluids trapped in pores of the overlying sediments. Desiccation and drawdown would have caused a progressive increase in salinity with depth, which is consistent with the increase in salinity observed at the KTB site (Emmermann and Lauterjung, 1997). The progressive increase in salinity and the corresponding reduction of $\mathrm{H}_{2} \mathrm{O}$ activity, near-exhaustive hydration of basement rocks, and/or reduction of porosity and permeability by hydration reactions can slow or even stop the process. Fluid pressure can begin to rise and equilibrate with the lithostatic pressure once it is no longer reduced by $\mathrm{H}_{2} \mathrm{O}$ consumption and/or permeability is sufficiently reduced by compaction and sealing. Over time, supra-hydrostatic fluid pressure may thus develop at depth.

Ingression of fluids since late Variscan times would have resulted in fluids increasing in age with depth, with the oldest fluids at the base of the column (Fig. 1C) being 100 m.y. old by the time of Jurassic ore formation. This is a conceivable residence time for basement fluids (Bottomley et al., 2002; Fehn and Snyder, 2005). These fluids modified their chemistry by reactive interaction with their rock matrix, while higher temperatures at depth allowed for efficient uptake of metals by chloride complexation (Yardley, 2005). This explains the low $\mathrm{Na} / \mathrm{Ca}$ ratio and elevated $\mathrm{Pb}$ and $\mathrm{Zn}$ concentrations of the saline deep basement fluid end member in the Schwarzwald (Fig. 1B; Fusswinkel et al., 2013). The deep basement fluids are also characterized by a low $\mathrm{Cl} / \mathrm{Br}$ ratio, typical of such fluids worldwide (Bucher and Stober, 2010, and references therein), which may be related to bittern ingression (Boiron et al., 2010; Wilkinson, 2010) during deposition of the Triassic evaporites or, alternatively, to leaching of basement rocks (e.g., Bucher and Stober, 2010).

After ca. $250 \mathrm{Ma}$, fluids entering from above were affected by the Triassic evaporites, which would have given them a high salinity and high $\mathrm{Cl} / \mathrm{Br}$ ratios (Bucher and Stober, 2010). With older fluids already residing at depth, these new fluids remained at shallower depths, where cooler temperatures inhibited extensive fluid-rock interaction. They could thus preserve their Triassic evaporite signature without significant uptake of metals or exchange of alkalis. These fluids constitute the saline, metal-poor, high $\mathrm{Cl} / \mathrm{Br}$, high $\mathrm{Na} / \mathrm{Ca}$ end member in the Schwarzwald (Fig. 1B). Today, the upper crustal fluid system in the Schwarzwald is still stratified, the uppermost $\sim 2 \mathrm{~km}$ being filled by a Ca- $\mathrm{HCO}_{3}$ water possibly related to carbonate dissolution at shallow depths; below this layer, typical continental Na-Cl brines are still present today (Bucher and Stober, 2010).

\section{Fluid ascent and mixing}

Fluid pressure in the crustal column increases from hydrostatic at the top to close to lithostatic at depth. Reduction of the overburden pressure, i.e., decompression, does not, initially, change the fluid pressure in pores as their volume remains approximately the same (Staude et al., 2009). This can cause the pore fluid pressure to exceed the 
host rock pressure, leading to the formation of fractures through which fluids can escape. Decompression can result from erosion or thinning of the crust, as well as crustal extension, where reduction of the horizontal stress reduces the pressure, which is the mean of the principal stresses. Staude et al. (2009) showed that decompression by crustal extension and thinning can provide sufficient fluids to produce the Jurassic ore deposits in the Schwarzwald.

Initial microcracks link up, creating ever-bigger fractures in a step-wise fashion, as described for fluids and melt (Bons and van Milligen, 2001). Once these hydrofractures, filled with buoyant fluid, exceed a critical length (on the order of tens of meters) they can become mobile by upward tip propagation and ascend rapidly through the crust (Weertman, 1971; Bons, 2001). Fluid is released from different levels of the column and expelled upwards. Deeper fluids ascend through shallower parts of the crust, causing mixing of fluids from various levels. Mixing is expected to be variable, with some batches quickly ascending without much interaction with other fluids, while others may merge and mix with other batches.

We suggest that ascending fluids are arrested at shallow crustal levels where fluid pressure is low, thus allowing fluids to spread into joints and fractures, or discontinuities, such as the post-Variscan unconformity. Bedding may also stop propagation of hydrofractures (Bons, 2001). The arrested fluids are strongly out of equilibrium with the conditions at their final arrest level. Disequilibrium and mixing of fluids with contrasting physicochemical properties cause efficient precipitation of dissolved mineral content to form ore deposits. The heterogeneous fluid signatures reflect the range of fluids sampled in the rock column below, as well as mixing between deep fluids and the high- $\mathrm{Cl} / \mathrm{Br}$ connate fluids in near-hydrostatic fluid reservoirs at shallow levels. Deposited minerals and metals depend on the lithologies below, especially at depth, where most elements are scavenged.

\section{Conclusions}

Mixing of fluids is common in unconformity-related hydrothermal ore deposits. Using the Schwarzwald district in Germany as an example, we propose that fluids first infiltrate into basement rocks from above. The oldest fluids reach the greatest depth, where these can equilibrate with their host rock and scavenge metals. The youngest fluids carry and maintain the signature of more recent sediments that were deposited on top of the unconformity. Rapidly ascending hydrofractures tap fluids from all levels of the infiltrated rock column, mixing these during ascent. The resulting mineral deposits thus show signatures of both fluid types. Separating fluid descent and ascent in time and mixing fluids during ascent provides a physically viable mechanism that explains the mineralogical and geochemical characteristics of the Schwarzwald ore deposits and may be applicable to many other unconformity-related hydrothermal ores.

\section{Acknowledgements}

This research was partly funded by German Research Foundation (DFG) grant BO 1776/8 and was carried out within the framework of DGMK (German Society for Petroleum and Coal Science and Technology) project 718, funded by the companies ExxonMobil Production Deutschland GmbH, GDF SUEZ E\&P Deutschland GmbH, RWE Dea AG, and Wintershall Holding GmbH. Assistance by Simone Kaulfuss, Gabi Stoschek, Sara Ladenburger, Mathias Burisch, and Bernd Steinhilber with sample preparation and crush-leach analyses is gratefully acknowledged. We thank Steve Cox and two anonymous reviewers for their critical comments. 


\section{References cited}

- Baatartsogt, B., Schwinn, G., Wagner, T., Taubald, H., Beitter, T., and Markl, G., 2007, Contrasting paleofluid systems in the continental basement: A fluid inclusion and stable isotope study of hydrothermal vein mineralization, Schwarzwald district, Germany: Geofluids, v. 7, p. 123147, doi:10.1111/j.1468-8123.2007.00169.x.

- Beaudoin, N., Bellahsen, N., Lacombe, O., Emmanuel, L., and Pironon, J., 2014, Crustalscale fluid flow during the tectonic evolution of the Bighorn Basin (Wyoming, USA): Basin Research, v. 26, p. 403435, doi:10.1111/bre.12032.

- Boiron, M.C., Cathelineau, M., and Richard, A., 2010, Fluid flows and metal deposition near basement/cover unconformity: Lessons and analogies from Pb-Zn-F-Ba systems for the understanding of Proterozoic U deposits: Geofluids, v. 10, p. 270292, doi:10.1111/j.1468 -8123 2010 .00289.x. Bons, P.D., 2001, The formation of large quartz veins by rapid ascent of fluids in mobile hydrofractures: Tectonophysics, v. 336, p. 117, doi:10.1016 /S00401951(01)00090-7.

- Bons, P.D., and Gomez-Rivas, E., 2013, Gravitational fractionation of isotopes and dissolved components as a first-order process in hydrothermal crustal fluids: Economic Geology and the Bulletin of the Society of Economic Geologists, v. 108, p. 11951201, doi:10.2113/econgeo .108 .5 .1195 .

- Bons, P.D., and van Milligen, B.P., 2001, New experiment to model self-organized critical transport and accumulation of melt and hydrocarbons from their source rocks: Geology, v. 29, p. 919922 , doi:10.1130/0091-7613

- Bons, P.D., Elburg, M.A., and Gomez-Rivas, E., 2012, A review of the formation of tectonic veins and their microstructures: Journal of Structural Geology, v. 43, p. 3362, doi: 10.1016 /j .jsg .2012.07.005.

- Bottomley, D.J., Renaud, R., Kotzer, T., and Clark, I.D., 2002, 129I constraints on residence times of deep marine brines in the Canadian Shield: Geology, v. 30, p. 587590, doi:10.1130/0091-7613 (2002) 030 ; 0587 :ICORTO ¿2.0.CO;2.

- Bucher, K., and Stober, I., 2010, Fluids in the upper continental crust: Geofluids, v. 10, p. 241253. Cox, S.F., 2010, The application of failure mode diagrams for exploring the roles of fluid pressure and stress states in controlling styles of fracture-controlled permeability enhancement in faults and shear zones: Geofluids, v. 10, p. 217233, doi:10.1111/j.14688123.2010.00281.x.

- Dahm, T., 2000, On the shape and velocity of fluid-filled fractures in the Earth: Geophysical Journal International, v. 142, p. 181192, doi:10.1046 /j .1365 -246x.2000.00148.x.

- Davies, G.R., and Smith, L.B., 2006, Structurally controlled hydrothermal dolomite reservoir facies: An overview: AAPG Bulletin, v. 90, p. 16411690, doi:10.1306/05220605164.

- de Marsily, G., 1986, Quantitative Hydrogeology: Groundwater Hydrology for Engineers: San Diego, California, Academic Press, Inc., 440 p.

- Emmermann, R., and Lauterjung, J., 1997, The German Continental Deep Drilling Program KTB: Overview and major results: Journal of Geophysical Research,v. 102, p. 18,17918,201, doi:10.1029/96JB03945.

- Fehn, U., and Snyder, G.T., 2005, Residence times and source ages of deep crustal fluids: Interpretation of $129 \mathrm{I}$ and $36 \mathrm{Cl}$ results from the KTB-VB drill site, Germany: Geofluids, v. 5, p. 4251, doi:10.1111/j.1468-8123.2004.00105.x.

- Fusswinkel, T., Wagner, T., Wlle, M., Wenzel, T., Heinrich, C.A., and Markl, M., 2013, Fluid mixing forms basement-hosted $\mathrm{Pb}-\mathrm{Zn}$ deposits: Insight from metal and halogen geochemistry of individual fluid inclusions: Geology, v. 41, p. 679682, doi:10.1130/G34092.1.

- Goldhaber, M.B., Church, S.E., Doe, B.R., Aleinikoff, J.N., Brannon, J.C., Podosek, F.A., Mosier, E.L., Taylor, C.D., and Gent, C.A., 1995, Lead and sulfur isotope investigation of Paleozoic sedimentary rocks from the southern mid-continent of the United States: Implications for paleohydrology and ore genesis of the southeast Missouri lead belts: Economic Geology and the Bulletin of the Society of Economic Geologists, v. 90, p. 18751910, doi: 10.2113 /gsecongeo .90.7.1875. 
- Hann, H.P., and Zedler, H., 2008, Variscan internides: Black Forest (Schwarzwald), in McCann, T., ed., The Geology of Central Europe, Variscan Tectonics, Volume 1: Precambrian and Palaeozoic: London, Geological Society of London, p. 599665.

- Kendrick, M.A., Honda, M., Oliver, N.H.S., and Phillips, D., 2011, The noble gas systematics of late-orogenic $\mathrm{H} 2 \mathrm{OCO} 2$ fluids, Mt Isa, Australia: Geochimica et Cosmochimica Acta, v. 75, p. 14281450 , doi:10.1016/j.gca.2010.12.005.

- Matthi, S.K., Heinrich, C.A., and Driesner, T., 2004, Is the Mount Isa copper deposit the product of forced brine convection in the footwall of a major reverse fault?: Geology, v. 32, p. 357360, doi:10.1130/G20108.1.

- Okamoto, A., and Tsuchiya, N., 2009, Velocity of vertical fluid ascent within vein-forming fractures: Geology, v. 37, p. 563566, doi:10.1130/G25680A.1.

- Oliver, N.H.S., McLellan, J.G., Hobbs, B.E., Cleverley, J.S., Ord, A., and Feltrin, L., 2006a, Numerical models of extensional deformation, heat transfer, and fluid flow across basementcover interfaces during basin-related mineralization: Economic Geology and the Bulletin of the Society of Economic Geologists, v. 101, p. 131, doi:10.2113/gsecongeo.101.1.1.

- Oliver, N.H.S., Rubenach, M.J., Fu, B., Baker, T., Blenkinsop, T.G., Cleverley, J.S., Marshall, L.J., and Ridd, P.J., 2006b, Granite-related overpressure and volatile release in the mid crust: Fluidized breccias from the Cloncurry District, Australia: Geofluids, v. 6, p. 346358, doi:10.1111/j.1468-8123.2006.00155.x.

- Person, M., Mulch, A., Teyssier, C., and Gao, Y., 2007, Isotope transport and exchange within metamorphic core complexes: American Journal of Science, v. 307, p. 555589, doi: 10.2475/03.2007.01.

- Schwinn, G., Wagner, T., Baatartsogt, B., and Markl, G., 2006, Quantification of mixing processes in ore-forming hydrothermal systems by combination of stable isotope and fluid inclusion analyses: Geochimica et Cosmochimica Acta, v. 70, p. 965982, doi:10.1016/j .gca.2005.10.022.

- Staude, S., Bons, P.D., and Markl, G., 2009, Hydrothermal vein formation by extensiondriven dewatering of the middle crust: An example from SW Germany: Earth and Planetary Science Letters, v. 286, p. 387395, doi:10.1016/j.epsl.2009.07.012.

- Staude, S., Mordhorst, T., Nau, S., Pfaff, K., Brgmann, G., Jacob, D.E., and Markl, G., 2012, Hydrothermal carbonates of the Schwarzwald ore district, southwestern Germany: Carbon source and conditions of formation using d18O, d13C, $87 \mathrm{Sr} / 86 \mathrm{Sr}$, and fluid inclusions: Canadian Mineralogist, v. 50, p. 14011434, doi:10.3749/canmin.50.5.1401.

- Stober, I., and Bucher, K., 2004, Fluid sinks within the Earths crust: Geofluids, v. 4, p. 143151, doi:10.1111/j.1468-8115.2004.00078.x.

- Wagner, T., Boyce, A.J., and Erzinger, J., 2010, Fluid-rock interaction during formation of metamorphic quartz veins: A REE and stable isotope study from the Rhenish Massif, Germany: American Journal of Science, v. 310, p. 645682, doi:10.2475/07.2010.04.

- Weertman, J., 1971, Velocity at which liquid-filled cracks move in the Earths crust or in glaciers: Journal of Geophysical Research, v. 76, p. 85448553, doi:10.1029/JB076i035p08544.

- Weisheit, A., Bons, P.D., and Elburg, M.A., 2013, Long-lived crustal-scale fluid-flow: The hydrothermal mega-breccia of Hidden Valley, Mt. Painter Inlier, South Australia: International Journal of Earth Sciences, v. 102, p. 12191236, doi:10.1007/s00531-013-0875-7.

- Wilkinson, J.J., 2010, A review of fluid inclusion constraints on mineralization in the Irish ore field and implications for the genesis of sediment-hosted $\mathrm{Zn}-\mathrm{Pb}$ deposits: Economic Geology and the Bulletin of the Society of Economic Geologists, v. 105, p. 417442, doi:10.2113/gsecongeo.105.2.417.

- Yardley, B.W.D., 2005, Metal concentrations in crustal fluids and their relationship to ore formation: Economic Geology and the Bulletin of the Society of Economic Geologists, v. 100, p. 613632, doi:10.2113/gsecongeo.100.4.613. 


\section{Online supplemental information}

Crush-leach and microthermometry

A Linkam THMSG-600 cooling-heating stage in connection with synthetic fluid inclusion standards was used to conduct microthermometric measurements (Table A1). Samples suitable for crush-leach analysis (c.f. those with only one fluid type) were crushed to a grain size of 0.5 to $1 \mathrm{~mm}$. Each $2 \mathrm{~g}$ per sample (fluorite, quartz, calcite) was carefully handpicked to remove visible impurities, heated in a beaker to $60-70 \mathrm{C}$ for 3 hours using concentrated HNO3 and washed twice a day with Milli-Q-water for one week. Subsequently, these samples were hand-crushed to a fine powder and $5 \mathrm{ml}$ acidulated Milli-Q-water $(\mathrm{pH}$ $\sim 2$ ) was added. These solutions were filtered (CROMAFILE@Xtra RC-20/25) and injected into a Dionex ICS 1000 ion chromatography system at the University of Tbingen equipped with an IonPac AS 9-HC $2 \mathrm{~mm}$ column for $\mathrm{Cl}$ and $\mathrm{Br}$ determination. Detection limits for $\mathrm{Cl}$ and $\mathrm{Br}$ were at the ppb level and based on the frequent analyses of standard solutions, relative uncertainties are generally $\leq 15 \%$ (1-sigma level). We checked for possible contamination by performing blank runs.

\begin{tabular}{|c|c|c|c|c|c|c|}
\hline Sample & latitude* & longitude* & location & $\begin{array}{l}\text { gangue } \\
\text { mineral }\end{array}$ & $\begin{array}{l}\text { salinity ( } \mathrm{NaCl} \\
+\mathrm{CaCl} 2)\end{array}$ & $\begin{array}{l}\mathrm{Cl} / \mathrm{Br} \\
\text { mass ratio }\end{array}$ \\
\hline F15 & 47.664267 & 7.923798 & Wehratal & fluorite & $21.5 \pm 0.5$ & $237 \pm 53$ \\
\hline F16 & 47.683817 & 8.253700 & Nggenschwiel & fluorite & $25.7 \pm 0.4$ & $117 \pm 35$ \\
\hline GS28a & 47.722646 & 8.120855 & Schwarzwaldsegen & fluorite & $22.7 \pm 0.5$ & $103 \pm 31$ \\
\hline $42 \mathrm{Fl}$ & 47.757750 & 8.279599 & Igelschlatt & fluorite & $23.2 \pm 0.5$ & $300 \pm 90$ \\
\hline BW32 & 47.757750 & 8.279599 & Igelschlatt & fluorite & $23.2 \pm 0.5$ & $161 \pm 48$ \\
\hline ML-23 & 47.757750 & 8.279599 & Igelschlatt & fluorite & $23.2 \pm 0.5$ & $267 \pm 80$ \\
\hline BW-22 & 47.832544 & 7.903407 & Finstergrund & fluorite & $25.5 \pm 0.3$ & $372 \pm 112$ \\
\hline ML-19 & 47.832544 & 7.903407 & Finstergrund & fluorite & $25.5 \pm 0.3$ & $423 \pm 127$ \\
\hline BW178 & 47.832544 & 7.903407 & Finstergrund & fluorite & $25.5 \pm 0.3$ & $170 \pm 51$ \\
\hline ML-37 & 47.830915 & 7.819548 & Herrenwald & quartz & $24.6 \pm 5.0$ & $185 \pm 55$ \\
\hline ML-13 & 47.909642 & 7.898767 & Schauinsland & quartz & $24.6 \pm 0.3$ & $118 \pm 35$ \\
\hline GS92 & 47.7414435 & 8.232401 & Brenden & fluorite & $22.9 \pm 1.3$ & $268 \pm 80$ \\
\hline $24 \mathrm{Fl}$ & 47.7414435 & 8.232401 & Brenden & fluorite & $22.9 \pm 1.3$ & $569 \pm 171$ \\
\hline BO90 & 47.859206 & 7.743900 & Wonnen Nord & quartz & $23.9 \pm 1.5$ & $117 \pm 35$ \\
\hline BW9 & 47.751106 & 8.108111 & $\begin{array}{l}\text { Neue Hoffnung } \\
\text { Gottes }\end{array}$ & fluorite & $22.1 \pm 1.0$ & $117 \pm 35$ \\
\hline ML-25 & 47.841301 & 7.972786 & Brandenberg & fluorite & $23.0 \pm 1.0$ & $132 \pm 40$ \\
\hline GS111F & 47.841301 & 7.972786 & Brandenberg & fluorite & $23.0 \pm 1.0$ & $133 \pm 40$ \\
\hline GS111Q & 47.841301 & 7.972786 & Brandenberg & quartz & $22.9 \pm 1.0$ & $151 \pm 45$ \\
\hline GS111 & 47.841301 & 7.972786 & Brandenberg & fluorite & $23.0 \pm 1.0$ & $131 \pm 39$ \\
\hline GS83 & 47.841301 & 7.972786 & Brandenberg & fluorite & $23.0 \pm 1.0$ & $296 \pm 89$ \\
\hline BW56 & 47.841301 & 7.972786 & Waldschweine & fluorite & $20.1 \pm 2.5$ & $177 \pm 53$ \\
\hline FP19 & 47.793183 & 7.798217 & Nonnenmattweiher & fluorite & $24.0 \pm 0.4$ & $85 \pm 26$ \\
\hline FP19 & 47.792210 & 7.796888 & Nonnenmattweiher & fluorite & $24.0 \pm 0.4$ & $59 \pm 18$ \\
\hline ML42 & 47.724685 & 8.120925 & Gottesehre Urberg & calcite & $19.8 \pm 3.2$ & $142 \pm 43$ \\
\hline
\end{tabular}

Table 1: Table A1. Crush-leach and microthermometry data 